\title{
DETERMINING THE VALUE OF THE ARROW-SIGN IN PHRYGIAN AND LYDIAN
}

\begin{abstract}
In this contribution the available evidence on the value of the arrow-sign $(\uparrow)$ in Phrygian and Lydian will be discussed. After examining the current point of view on the topic, which favors a sibilant value, it will be argued that a dental value is to be preferred not only from an epigraphical point of view but also, and most emphatically so, from a linguistic point of view.
\end{abstract}

Key words. - arrow-sign, epigraphic, Cypro-Minoan, linguistic, Phrygian, relationship to (Mycenaean) Greek, Lydian, relationship to Luwian.

In the Phrygian and Lydian scripts we come across a sign in the form of an arrow, $\uparrow$, of which it is still subject to debate which value it renders.

With respect to the Phrygian arrow-sign it has been suggested by Claude Brixhe, basing himself on an earlier hunch by J. Fraser, ${ }^{1}$ that it is identical to the sign called sampi, T, known from the Ionian Greek alphabets of western Anatolia, in which it expresses the value $/ \mathrm{ss} / .^{2}$ In line with this analysis, Brixhe assumes that the Phrygian arrowsign expresses a sibilant value, /ts/, which in his (and Fraser's) view originates from palatalization of the voiceless palatovelar * $\bar{k}^{3}$

A slightly different, but essentially similar, line of approach is taken by Günter Neumann, who transliterates the Phrygian arrow-sign by $s$ and maintains that it corresponds to New Phrygian $\zeta$ (or $/ \mathrm{dz} /$ ) as in case of (in his reading) sira- (Vezirhan, line 11), which he interprets in accordance with its similarity in form to New Phrygian $\zeta \varepsilon 1 \rho \alpha$ "hand". As rightly inferred by Zsolt Simon, this leads us to the conclusion that $s$ in Neumann's view originates from the aspirated voiced

\footnotetext{
${ }^{1}$ Fraser, The Lydian Language, 143.

${ }^{2}$ Brixhe, Palatalisations en grec, 229-230.

${ }^{3}$ Brixhe, Palatalisations en grec, 232-237; Brixhe, Corpus, Supplément II, 26-28; 43; cf. Gorbachov, Nine Observations, 92, note 2.

${ }^{4}$ Neumann, Die zwei Inschriften, 25.
} 
palatovelar $* \hat{g}^{h}$ as śira- or $\zeta \varepsilon 1 \rho \alpha$ can be positively traced back to Proto-Indo-European (= PIE) * $\hat{g}^{h} e_{s} r$ - "hand".

Moreover, Craig Melchert, in personal communications cited by Ignasi-Xavier Adiego, maintains that the Phrygian arrow-sign originates from a Luwian hieroglyphic counterpart, no. 376 I (in Laroche's numbering), which according to the so-called new reading exclusively renders the sibilant value $z i$ tsi/ or, in Late Bronze Age texts, also $z a$ /tsa/, and hence he actually sides with Neumann in assuming that it renders the value $/ \mathrm{dz} / .^{6}$

Finally, Bartomeu Obrador-Cursach in his recent book on the Phrygian language maintains that the arrow-sign is a variant of Phoenician giml, used for the expression of a fricative allophone $/ \mathrm{z} /$ or palatal $/ \mathrm{g}^{\mathrm{j}} /, / \mathrm{zd} /, / \mathrm{dz} /$. Like Brixhe, he groups it with sampi. ${ }^{7}$

According to the present communis opinio as represented by Roberto Gusmani the Lydian arrow-sign renders the value $c /$ ts $/ .{ }^{8}$ This opinion, however, is maintained with the proviso that "durch einige überzeugende Etymologien (...) wahrscheinlich gemacht [wird], daß $c$ wenigstens zum Teil auf einen Dentallaut zurückgeht". ${ }^{9}$ Such a dental value can further be underlined by the apparent cases of interchange with on the one hand the normal $t(\uparrow i v-/ t i v$ - in the personal name Tivdaś; $\uparrow a t i-/ \operatorname{ta}(a) \uparrow\left(i_{1}\right)$ - and taśe $\left.\tilde{e}^{-}\right)$and on the other hand the secondary $t$

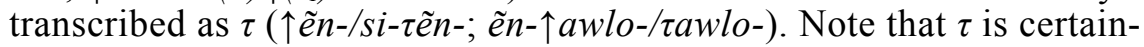

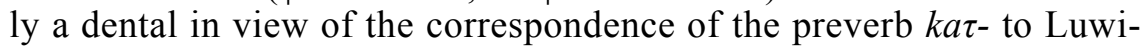
an hieroglyphic kata.

Now, the dental value of the Lydian arrow-sign can be underlined by more cases than the four cited by Gusmani and the given interchanges with $t$ and $\tau$, as deducible from the overview in our Table II. As a matter of fact, it is the "Zischlaut" part which is in need of confirmation.

This raises the question: is the sibilant value assumed for the Phrygian arrow-sign incorrect as well and does it not, like its Lydian counterpart, render a dental value?

From an epigraphical point of view, it can be remarked that the arrow-sign $(\uparrow)$ is not identical to the Ionian sampi $(\mathrm{T})$, but clearly distinct from it as the given forms make clear. Moreover, this distinction can be further underlined by the attestation of the sampi in the Old Phrygian inscription P-106 from Pteria. ${ }^{10}$ Similarly, the arrow-sign ( $\uparrow$ )

\footnotetext{
${ }^{5}$ Simon, Die letzte Zeile, 26; for the PIE roots, see Mallory \& Adams, The Oxford Introduction.

${ }^{6}$ Adiego, Local Adaptations, 149.

${ }^{7}$ Obrador-Cursach, The Phrygian Language, 31-37.

${ }^{8}$ Gusmani, Lydisches Wörterbuch, 32: "dentalen Zischlaut".

${ }^{9}$ Gusmani, Lydisches Wörterbuch, 33.

${ }^{10}$ Brixhe, Palatalisations en grec, 231 ; for the Old Phrygian texts, see Brixhe \& Lejeune, Corpus des Inscriptions.
} 
is not identical to Luwian hieroglyphic no. 376 (I) either, as in the latter case the slanting bar on right continues a little bit to the left at the top side of the vertical bar. As I have argued from the early 1980s onwards, the closest comparative evidence for the arrow-sign ( $\uparrow$ ) is provided by the Cypro-Minoan ti-sign, which also represents a symmetrical arrow, $\uparrow$.

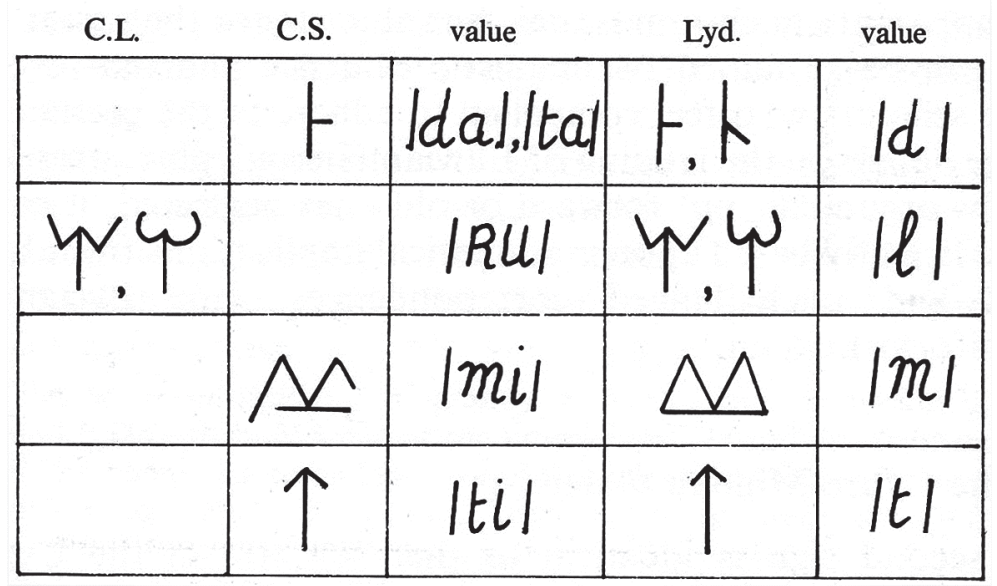

Fig. 1. Lydian supplementary signs originating from the Cypro-Minoan script or its predecessor, Cretan Linear (Woudhuizen, Lydian: Separated from Luwian, 98, Fig. 2).

The arrow shaped $t i$-sign is not an isolated instance of borrowing by the Lydian alphabet from the Cypro-Minoan syllabary (or its ancestral Linear B), but the same applies for its signs for $d, \lambda$, and "Carian" $m$ from the earliest set of inscriptions, ${ }^{12}$ originating from Cypro-Minoan $t a$ (Linear B da), Linear B ru (also lu), and Cypro-Minoan $m i$, respectively (see Fig. 1).

In all these three instances, the original syllabic value is regularly reduced to an alphabetic one by the acrophonic principle, so along this same line of reasoning a dental value, $t<t i$, for the Lydian arrowsign lies at hand from an epigraphical point of view. We have already noted, that a dental value of the Lydian arrow-signs is also the most feasible one from a linguistic point of view, as will be elaborated below.

Does the in this manner epigraphically based dental value apply to the Phrygian arrow-sign as well? In principle, a supplementary sign can be used either for its original value or a secondary one, just like an alphabetic sign sometimes is used for the expression of a secondary value (like in case of the supplementary sign no. 26 in the Greek alphabet,

${ }^{11}$ Woudhuizen, Lydian: Separated from Luwian, 97-100; esp. 98, Fig. 2; Woudhuizen, Appendix IV: The Lydian-Aramaic, 127-130.

${ }^{12}$ Gusmani, Neue epichorische Schriftzeugnisse, 90; C I 1 ${ }^{2}$, C I 6, C II 1. 
an oldfashioned form of kap, for the related value / khi/ or entirely unrelated value /psi/). As shown in our Table I, there are a number of arguments that the Phrygian arrow-sign, just like its Lydian counterpart, expresses a dental value.

The first argument is based on a bilingual footing. As observed by Yaroslav Gorbachov, sin-t imenan (A sg.) in line 8 of the bilingual inscription from Vezirhan in Bithynia (B-05, 5th or 4th century BC) corresponds to Greek $\tau$ ò ípòv. ${ }^{13}$ As I have argued in my contribution on Phrygian of 2008-9, ${ }^{14}$ the object in the Phrygian version of the protasis of the damnation formula should be read sin timenan specifying the holy site as a $\tau \dot{\varepsilon} \mu \varepsilon v o \varsigma$ "temple". ${ }^{15}$ Now, this same indication of the precinct recurs in line 13 in variant writing $\uparrow$ emeney (D sg.), thus proving beyond doubt that the arrow-sign expresses a dental value, to be transliterated as $t_{1}{ }^{16}$

The second argument is also of a high evidential value. In a tumulus burial of a female person, probably a priestess, at Bayındır in Lycia dating from the late 8th century BC there have been found Phrygian dedicatory inscriptions on bronze and silver bowls, small silver cauldrons, and a silver ladle. Among these inscriptions features six times the legend ates, presumably a reference to the Phrygian deity Attis (HP-103-108). Once, however, this legend occurs in writing variant with the arrow-sign followed by a crooked iota (not a sigma as Brixhe wants to have it, the latter sign being distinguished here by its fivestroked variant form), reading a个ies in sum (HP-109). ${ }^{17}$ Clearly, we are dealing here with a writing variant of the GN Attis more closely resembling New Phrygian Attie (D sg.) as attested in NPhr- $45 .{ }^{18}$ The correct reading of this particular legend therefore is $A t_{1} i e s .{ }^{19}$

Next, one of the inscriptions from the same tumulus D at Bayindir, on an omphalos bowl, reads si个idos (HP-110). As rightly observed by Brixhe, this recalls the legend si个idosakor on a bronze bowl from tumulus MM at Gordion, dated to $c .740 \mathrm{BC} .^{20}$ See now also si $\uparrow$ idos in G-346 as found on a roof beam also from tumulus MM. ${ }^{21}$ Now, as the bronze bowl in question likely served for food offerings at the time of

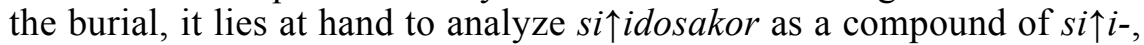

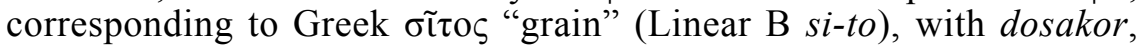

${ }^{13}$ Gorbachov, Nine Observations, 97.

${ }^{14}$ Woudhuizen, Phrygian \& Greek.

${ }^{15} \mathrm{Cf}$. Linear B te-me-no "area of land set aside for a chieftain", see Ventris \& Chadwick, Documents, glossary, s.v.

${ }^{16}$ Woudhuizen, Phrygian \& Greek, 190, note 11.

${ }^{17}$ Cf. Brixhe, Corpus, Supplément II, 114-115; 130.

${ }^{18}$ Woudhuizen, Phrygian \& Greek, 203.

${ }^{19}$ Woudhuizen, The Transmission, 182.

${ }^{20}$ Brixhe \& Lejeune, Corpus des Inscriptions, G-105; cf. Brixhe, Corpus, Supplément II, 115 .

${ }^{21}$ Obrador-Cursach, The Phrygian Language, 499. 


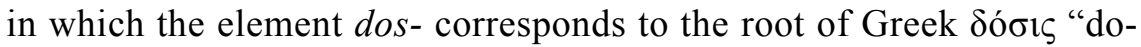
se" (cf. Linear B do-so-mo /dosmōi/ "as a present") and likewise can be traced back to PIE *deh $3^{-}$"to give". ${ }^{22}$ The correct reading and interpretation, therefore, of this legend is sit idosakor "grain offering".

In line with the preceding identification, the root of the verbal form si $\uparrow e t o$, characterized by a lenited writing variant of the ending of the 3 rd person singular of the imperative of the middle in -do, as attested for two rock inscriptions from Midas City dating from the late 8th or 7 th century $\mathrm{BC},{ }^{23} s i \uparrow e-$, is likely to be interpreted as being related

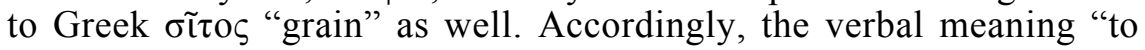
nourish" lies at hand for it, and the entire phrase 3 of the inscriptions

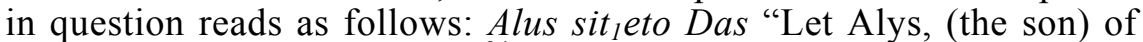
Mother Earth, be nourished!". ${ }^{24}$

The dental nature of the arrow-sign in the root $s i \uparrow$ - receives substantial confirmation by the element sito- as evidenced for a Phrygian inscription from Seytömer Höyük (W-12), which the authors, like I do with $s i \uparrow-$, compare to Greek бĩ $\varsigma^{\text {"grain". }}{ }^{25}$ At any rate, there can be little doubt that we have here a writing variant of the same root in which the arrow-sign is rendered by the common tau.

Against the backdrop of the foregoing evidence for the dental value of the arrow-sign and its transcription as $t_{1}$, it lies at hand that the apparent interchange of the arrow-sign with $\varphi$ in kpianaveyos in

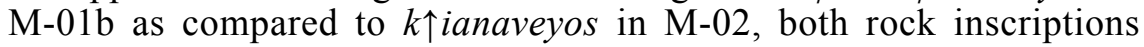
from Midas City dating from the late 8 th century $\mathrm{BC}$, is due to a scribal error indicating the unfamiliarity of the scribe with the supplementary sign no. $25 \varphi .{ }^{26}$ At any rate, the root of the form in question bears testimony of the TN Tyana, ${ }^{27}$ where the brother or half-brother of Midas, Babas, was stationed as governor, ${ }^{28}$ and $K t_{1}$ iana- comes into consideration of a fortified or velarized pronunciation of the initial dental whereas $\dagger$ Kphiana- does not.

The evidence discussed in the above for the dental value $t_{l}$ of the Phrygian arrow-sign $(\uparrow)$ can be summarized as follows (see Table I):

${ }^{22}$ Woudhuizen, Phrygian \& Greek, 189; 185; for Linear B, see Ventris \& Chadwick, Documents, glossary, s.v.

${ }^{23}$ Brixhe \& Lejeune, Corpus des Inscriptions, W-08; W-10.

${ }^{24}$ Woudhuizen, Phrygian \& Greek, 196-197.

${ }^{25}$ Bilgen, Brixhe \& Coşkun, Une nouveau site, 148; cf. Obrador-Cursach, The Phrygian Language, 437.

${ }^{26}$ Woudhuizen, The Luwian Hieroglyphic Contribution, 8.

${ }^{27}$ Zgusta, Kleinasiatische Ortsnamen, 637.

${ }^{28}$ Brixhe \& Lejeiune, Corpus des Inscriptions, T-02; Woudhuizen, Phrygian \& Greek, 193. 


\begin{tabular}{|c|c|c|c|}
\hline & Attestation & etymology & source \\
\hline 1. & $k \uparrow i a n a v e y o s$ & Tyana (TN) & M-02 \\
\hline 2. & si eto & 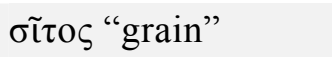 & W-08; W-10 \\
\hline 3. & si idos(akor) & 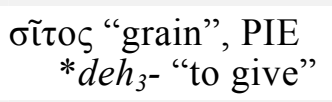 & $\begin{array}{c}\text { G-105; G-346; } \\
\text { HP-110 }\end{array}$ \\
\hline 4. & $\uparrow$ emeney (D sg.) & 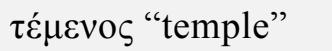 & B- 05,13 \\
\hline 5. & a个ies & Attis (GN) & НР-109 \\
\hline
\end{tabular}

Table I. Overview of the Phrygian evidence for the dental value of the arrow-sign $(\uparrow)$.

As Neumann's interpretation of $\uparrow i r a$ - from the Vezirhan inscription (B-05) in line with NPhr $\zeta \varepsilon t \rho \alpha$ "hand" is without proper foundation - there is no corresponding form for "hand" in the Greek text -, positive linguistic evidence for the only alternative reading of the arrow-sign as a sibilant is entirely lacking, so the given indications as to its dental value up to this moment go unchallenged.

The arrow-sign can also be traced in Lycian. In inscriptions from the classical period, it renders the secondary value $e$. As opposed to this, in a 7 th century BC inscription from Rhodes, which reads $u r \uparrow u$ (N 300), it likely still renders the original value $t_{2}$. At any rate, the reading $u r t_{2} u$ corresponds to Lycian B $u r t u-{ }^{29}$

If we next turn to the Lydian evidence, we have already noted that Gusmani acknowledges that in four cases the arrow-sign ( $\uparrow$ ), transliterated by him as $c /$ ts $/$, can be shown to render of origin a dental value.

The first case entails the verbal root $v i \uparrow-$, which from an etymological point of view can be compared to Hittite weda-/wete- "to build". ${ }^{30}$ This verbal root is twice represented in the form $v i \uparrow i_{l}$, characterized by the ending of the 3 rd person singular of the present/future of the active in $-i_{1}$, corresponding to cuneiform Luwian $-i^{31}$ and Lycian $-i^{32}$ for the same function, attested for Lyd. no. 22, line 1 and Lyd. no. 11, lines 1-2 in a context that suggests its use as a praesens historicum for the expression of the past tense: est mrud (...)

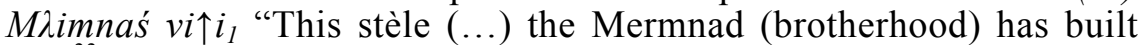

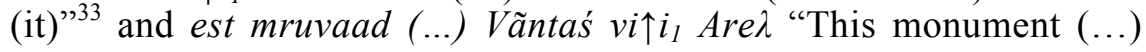

\footnotetext{
${ }^{29}$ Woudhuizen, Lydian: Separated from Luwian, 98, note 38; Melchert, A Dictionary, 133.

${ }^{30}$ Gusmani, Lydisches Wörterbuch, 225; for Hittite forms, cf. Friedrich, Kurzgefaßtes Hethitisches, s.v.

${ }^{31}$ Woudhuizen, Selected Cuneiform, 358.

${ }^{32}$ Melchert, A Dictionary, xii.

${ }^{33}$ Woudhuizen, The Role of Brotherhoods, 175-176.
} 
Vantas has built (it) for Ares". Given the etymological correspondence to Hittite weda-/wete-, the transliteration of the arrow sign as $t_{1}$, and hence the verbal form as $v i t_{1} i_{l}$, lies at hand. Note that my transliteration of the sign rendered by Greek $\uparrow v / \mathrm{n} /$ according to current practices as $i_{1}$ is based on its identification with the Phoenician yôd. ${ }^{34}$

The second case concerns the noun $\uparrow i v$ - "god", which is compared to Hittite siuni-, suggesting a sibilant value at first sight. Both the Lydian and Hittite form, though, are traced back to PIE *dyew"god". What Gusmani does not indicate, however, is that the Luwian hieroglyphic equivalent Tiwata- "(sun-)god" 36 is much more to the point than the given Hittite comparison. This can be further underlined by the fact that the root $\uparrow i v$ - occurs in graphic variant $t i v$ - in the personal name Tivdas..$^{37}$ Also in connection with the word $\uparrow i v-$ "god", therefore, a transliteration of the arrow-sign as $t_{l}$ is to be preferred.

The third case has a bearing on the verb $\uparrow a t i-$ "to dedicate", which Gusmani analyzes as a derivative in - $t i$ - of the verbal root $\uparrow a$-, originating from PIE $* d^{h} \bar{e}$ - "to put" and comparable to, amongst others, Lycian $t a$ - "to put, place" ${ }^{, 38}$ and the root of the Luwian hieroglyphic factitive in -nuwa-, tanuwa- "to cause to stand, erect, set up", and more distantly, that of Phrygian edaes "he has dedicated" and Greek $\alpha \dot{\alpha} \theta \eta \uparrow \varepsilon{ }^{39}$ This verb is attested in the 3rd person singular of the present/future tense of the active in - $t$, corresponding to cuneiform $\mathrm{Lu}$ wian $-t i$, Luwian hieroglyphic $-t i$, and Lycian $-d / t i$ for the same function, ${ }^{40}$ used as a praesens historicum for the expression of the past tense, in the bilingual inscription Lyd. no. 40, lines 1-2: esi ${ }_{1}$ taśé $i_{1}{ }^{A} A s i_{1} i l$ Bartaraś $\uparrow a t i t$ "This stèle for Asia, Bartaras has erected (it)." Note that the Luwian goddess Asia ( $<$ Assiya-, based on the verbal root assiya- "to (be) love(d)", hence "the beloved goddess") is represented by Athena in the corresponding Greek text. Again, the most likely transliteration of the arrow-sign in this case is a dental, $t_{l}$. The more so, because the same root $\uparrow a$ - occurs in graphic variant $t a$ - in the nominal derivatives $t a(a) \uparrow\left(i_{1}\right)$ - (Lyd. no. 45, line 5; etc.) and taśẽ- (Lyd. no. 40, line 1 ), both meaning "stèle" — notwithstanding Gusmani's disclaimer. $^{41}$

${ }^{34}$ So already Littmann, Sardis VI, 17; Woudhuizen, Lydian: Separated from Luwian, 92-97; Woudhuizen, Appendix IV: The Lydian-Aramaic, 124-127; Woudhuizen, Two Notes on Lydian, 207-208, esp. note 1 with reference to Gusmani, Zum Stand der Erforschung, 12: "vielleicht direct aus dem phönikischen, wo es yod bezeichnet".

${ }^{35}$ Gusmani, Lydisches Wörterbuch, 92.

${ }^{36}$ For the Luwian hieroglyphic forms, see Woudhuizen, Selected Luwian Hieroglyphic, indices, s.v.

${ }^{37}$ Gusmani, Lydisches Wörterbuch, 213.

${ }^{38}$ Melchert, A Dictionary, 59-60.

${ }^{39}$ Gusmani, Lydisches Wörterbuch, 87-88.

${ }^{40}$ Woudhuizen, Selected Luwian Hieroglyphic, 432.

${ }^{41}$ Gusmani, Lydisches Wörterbuch, 207; 211. 
The fourth case concerns the verbal root $\uparrow u(v e)$ - "to erect", which Gusmani rightly connects with cuneiform Luwian duwa-, Luwian hieroglyphic tuwa-, and Lycian tuwe- of the same meaning. ${ }^{42}$ Notwithstanding the fact that this root is attested in a composite form, da个uverśt, which occurs in a thus far unclarified context (Lyd. no. 23, line 1), its clear etymological background once again suggests a dental reading of the arrow-sign, $t_{l}$.

These four examples for the dental value of the Lydian arrowsign can be supplemented by seven other cases.

In the first place, the verbal root $v \uparrow b(a) i-$, which features so prominently in the apodosis of the damnation formula, can be positively linked up with cuneiform Luwian dupai-, Luwian hieroglyphic tupi-, and Lycian tub(e)i-, all meaning "to strike, hit". ${ }^{43}$ Accordingly, the apodosis of the damnation formula in Lyd. no. 4b, lines 4-5 reads as

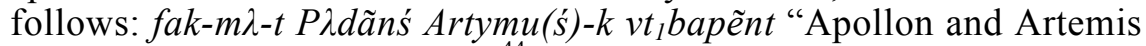
will strike him because of it". ${ }^{44}$ This interpretation is further underlined by the fact that in the corresponding section of the bilingual with Aramaic, Lyd. no. 1, lines 7-9, vt $t_{l}$ bapent is matched by ybdrwn- $h w$ $y p t-h$ "zerstreuen sollen sie ihm und zerbrechen soll sie ihm" in the Aramaic version. ${ }^{45}$ Note that the verbal form renders the 3 rd person plural of active in - $n t$, related to cuneiform Luwian - nti, Luwian hieroglyphic ${ }^{n} t i$, and Lycian $-\tilde{n} t i$ for the same function. ${ }^{46}$ The extension of the root in form of - $p \tilde{e}-$ remains elusive for the lack of a comparison. The transliteration of the sign + as $p$, instead of $\uparrow q$ as Gusmani has it, is based, inter alia, on the identification of the GN P $\lambda d \tilde{a n n s}$ as a reflex of Greek Apollon. ${ }^{47}$

Next, the verbal root $d \uparrow t d i$, , which occurs in an advance section of the protasis of the damnation formula of Lyd. no. 2 after the instance of fẽns $\lambda$ ibid "he will bring damage to", the verbal form which regularly characterizes this section, may likely be etymologically connected to Lycian $t t l(e) i-$ "to pay". ${ }^{48}$ If we realize that Greek $\tau \varepsilon \lambda \dot{\varepsilon} \omega$ "to pay" is also used for the expression "to sacrifice", it may reasonably be argued that the form $d \uparrow t d i d$ in line 8 has no bearing on the infliction of damage, the sense already expressed by fẽns $\lambda$ ibid in line 5 , but on sacrifices made secondarily in an illegal way (i.e. not on behalf of the owner of the grave and his family) or, perhaps better, sacrifices appropriated on behalf of others than the owner himself. If so, the re-

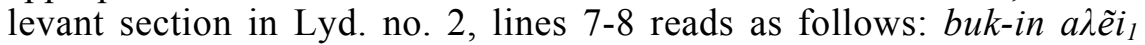
avlãi $i_{1}$ pisk $d t_{1}$ tdid ist esh vãna "or whoever sacrifices something (-in)

\footnotetext{
${ }^{42}$ Gusmani, Lydisches Wörterbuch, 94.

${ }^{43}$ Woudhuizen, Selected Luwian Hieroglyphic, 429; Melchert, A Dictionary, 72.

${ }^{44}$ Cf. Woudhuizen, Lydian: Separated from Luwian, 100.

${ }^{45}$ Woudhuizen, Appendix IV: Lydian-Aramaic, 121; 128-130.

${ }^{46}$ Woudhuizen, Selected Luwian Hieroglyphic, 432.

${ }^{47}$ Woudhuizen, Lydian: Separated from Luwian, 101-102.

${ }^{48}$ Melchert, A Dictionary, 68.
} 
in this grave to any other persons". ${ }^{49}$ Note that the verbal ending in $-d$ is a graphic variant of the one in $-t$ we came across in the discussion of $\uparrow a t i t$ above and that the same graphic variation typifies Lycian $-d / t i$.

Apart from the bilingual text Lyd. no. 1, the contents of the longer Lydian inscriptions are still only understood in a lacunary way. An exception is formed by Lyd. no. 22, thanks to the admirably clear structural analysis by Ilya Yakubovich. ${ }^{50}$ Now, in this reasonably well understood longer text ${ }^{51}$ there can be found, apart from vit $i_{1} i_{1}$ (line 1) and $v t_{1} b(a) i$ - (line 13) already discussed in the above, four more instances of the arrow-sign: fa $i_{1}$ iris (line 1), $\uparrow i d a \lambda m d a i_{1}$ (line 6), $\uparrow \tilde{e n t}$ (line 8), and $\uparrow \tilde{e}$ prà (line 12).

Of these four instances, fa个iliris renders the accusative plural of the communal gender in -is, corresponding to Lycian -is for the same function, ${ }^{52}$ of the root $f a \uparrow i_{1} i r-$. Now, the meaning of this root can be recovered from oblivion owing to its etymological relationship to Phrygian pater- "Father" (< Greek $\pi \alpha \tau \eta ́ \rho)$, denoting a senior religious official in NPhr-98. ${ }^{53}$ Accordingly, we arrive at a dental transliteration of the arrow-sign in this instance, hence $f_{a t} t_{1} i_{1} i r$ -

Next, $\uparrow i d a \lambda m d a i_{1}$ confronts us with the genitive plural in $-a i_{1}$, corresponding to Luwian hieroglyphic $-a i$ or $-a \bar{l}$ and Lycian $-\tilde{a} i$ for the same function, ${ }^{54}$ of the root $\uparrow i d a \lambda m d-$. This root in turn may be analyzed as a formation in - $m d$ - (cf. Greek $\Lambda v \kappa о \mu i ́ \delta \alpha \imath)$ of the more basic root $\uparrow i d a \lambda$-, the first part of which, $\uparrow i d a-$, recalls Lycian tideimi- "son, child", a participial formation in - $m i$ - of the root tidei- "to nurture". ${ }^{55}$ Along this line of approach, the form under consideration refers to the "nurtured Ones" as a form of address of the deities venerated in the temple. All in all, this leads us to the transliteration of the arrow-sign by dental $t_{1}$, hence $t_{1} i d a \lambda m d$ -

The third case concerns $\uparrow \tilde{e} n t$, the 3 rd person singular of the present/furure tense of the active in $-t$ (see $\uparrow$ atit above), of the verbal root $\uparrow \tilde{e} n-$. Of this verbal root, the morpheme $-n$ - remains elusive (shorthand variant of the factitive in -nuwa-?), but the meaning of the basic root $\uparrow \tilde{e}$ - can positively be retrieved on account of its correspondence to

${ }^{49}$ Cf. Woudhuizen, Lydian: Separated from Luwian, 100; note that avl- does not refer to a thing or object from the grave, but to a person, which enables us to trace it back to Akkadian awīlu "man", see Friedrich, Kurzgefaßtes Hethitisches, Akkadische Wörter, s.v.

${ }^{50}$ Yakubovich, An Agreement.

${ }^{51}$ For a detailed interpretation, see Woudhuizen, The Role of Brotherhoods, 173-179.

${ }^{52}$ Melchert, A Dictionary, x-xi.

${ }^{53}$ Woudhuizen, Phrygian \& Greek, 189; 212.

${ }^{54}$ Woudhuizen, The Genitive Plural.

55 Melchert, A Dictionary, 66; cf. cuneiform Luwian titaimma/i- "nurturing" < *tit(a)i- "to nurse, suckle", see Melchert, Cuneiform Luvian Lexicon, 228. 
Luwian hieroglyphic $t a$ - "to take". ${ }^{56}$ Once more the verdict is therefore that the arrow-sign renders a dental value, $t_{l}$, and that the correct transliteration of the verb is $t_{l} \tilde{e} n-$.

Perhaps most speculative is the fourth case, $\uparrow \tilde{e} p r a \lambda$. The mea-

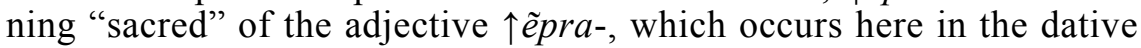
singular in $-\lambda$, is not in doubt, but for its etymological background I am inclined to point to the Luwian verb tapara- "to rule". The semantic difference may perhaps be bridged by the plausible suggestion that the meaning of the magistracy taparna- (or labarna-) "ruler" in the course of time shifted from the designation of a secular functionary to a religious one, analogous to Greek $\beta \alpha \sigma i \lambda \varepsilon v$ s. In this manner, then, a "ruling" became "sacred". If so, the dental transliteration of the arrowsign is etymologically assured also in this particular instance and we hence arrive at its reading as $t_{1} \tilde{e} p r a-$.

The arrow-sign also features in the protasis of the damnationformula of Lyd. no. in the object $\uparrow$ italad. The root of this form has been compared by Gusmani to Hittite idalu-, cuneiform Luwian adduwa$l i-$, and Luwian hieroglyphic atuwali- "bad, malice" ${ }^{57}$ This comparison decidedly indicates a dental reading of the arrow-sign, as $t_{1}$ italarelates to adduwali- in like manner as the Luwian hieroglyphic placename Tìtarma- (Köylütolu $\S \S 2$ and 7) to Hittite Attarima-. Accordingly, the protasis of the damnation-formula of Lyd. no. 5, lines 3-4

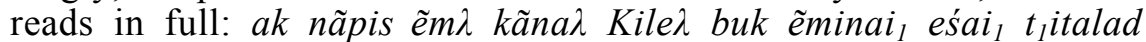
fadint "Whoever will cause something bad for my wife Killa or my descendants". Also in this particular case, therefore, there can be little doubt that a dental value for the arrow-sign applies.

Finally, the arrow-sign also features in an ending. This is the case in the apodosis of the damnation formula in Lyd. no. 6, lines 5-6: fak-ai $i_{1}$ viśśs niviśś $\uparrow i_{1}$ varbtokid "for these (offences) he will rule the good in hell" ${ }^{58}$ The form niviśs $\uparrow i_{1}$ refers to a location, expressed by the locative singular in $-\uparrow i_{1}$, which is the opposite of viśś- "good" owing to the use of the negative ni- "not", so that modern "hell" suggests itself. At any rate, the locative singular also occurs in form of $d i_{l}$, corresponding to Luwian hieroglyphic $-t i$ for the same function, ${ }^{59}$ for which reason the dental value for the arrow-sign suggests itself, hence niviśśt $t_{1} i_{1}$.

This leads us to the following overview of the evidence in favor of a dental value of the Lydian arrow-sign (see Table II):

\footnotetext{
${ }^{56}$ Woudhuizen, Selected Luwian Hieroglyphic, 143.

${ }^{57}$ Gusmani, Lydisches Wörterbuch, 91.

${ }^{58}$ Woudhuizen, Two Notes on Lydian, 211.

${ }^{59}$ Woudhuizen, Selected Luwian Hieroglyphic, 432.
} 


\begin{tabular}{|c|c|c|c|}
\hline & Attestation & etymology & source \\
\hline 1. & $v i \uparrow\left(i_{1}\right)-$ & Hit. weda-/wete- "to build" & Lyd. 11, 1-2; 22, 1 \\
\hline 2. & $\uparrow i v-$ & PIE * dyew- "god" & Lyd. 44, 17; etc. \\
\hline 3. & $\uparrow a t i-$ & PIE $* d^{h} \bar{e}-$ "to put" & Lyd. 40, 2 \\
\hline 4. & $\uparrow u(v e)-$ & Luw. tuwa- "to place, put" & Lyd. 23, 1 \\
\hline 5. & $v \uparrow b a-$ & Luw. tup $(a) i-$ "to strike, hit" & Lyd. 4b, 4-5; etc. \\
\hline 6. & $d \uparrow t d i-$ & Lyc. $t t l(e) i-$ "to pay" & Lyd. 2, 8 \\
\hline 7. & $f a \uparrow i_{1} i r-$ & Phryg. pater- "father" & Lyd. 22, 1 \\
\hline 8. & $\uparrow i d a \lambda m d-$ & Lyc. tideimi- "son, child" & Lyd. 22, 6 \\
\hline 9. & $\uparrow \tilde{e n}-$ & Luw. hier. ta- "to take" & Lyd. 22, 8; etc. \\
\hline 10. & $\uparrow$ ẽpra- & Luw. tapara- "to rule" & Lyd. 22, 12; etc. \\
\hline 11. & $\uparrow$ itala- & Luw. adduwali- "bad, malice" & Lyd. 5, 4 \\
\hline 12. & $-\uparrow i_{1}$ & $-d i_{1}$ (Loc. sg.) & Lyd. 6, 5; etc. \\
\hline
\end{tabular}

Table II. Overview of the Lydian evidence for the dental value of the arrow-sign ( $\uparrow$ )

As in case with the Phrygian arrow-sign, positive linguistic evidence for the only alternative reading of the Lydian arrow-sign as a sibilant /ts/, whatever the extent of its dental qualities, is entirely lacking, so the onus probandi for its transliteration otherwise than by dental $t_{1}$ lies with the critics.

\section{BIBLIOGRAPHY}

Adiego, Ignasi-Xavier. "Local Adaptations of the Alphabet among the Non-Greek Peoples of Anatolia." In: Ferrara, Silvia, \& Valério, Miguel, (eds), Paths into Script Formation in the Ancient Mediterranean. Studi Micenei ed Egeo-Anatolici, Nuova Serie, Supplemento 1, Roma, 2018, pp. 145-162.

Bilgen, A. Nejat, Brixhe, Claude, \& Coşkun, Gokhan. "Une nouveau site épigraphique paléo-phrygien: Seytömer Höyük", Kadmos 50, 2011, pp. 141-150.

Brixhe, Claude. "Palatalisations en grec et en phrygien", Bulletin de la Société de

Linguistique 77, 1982, pp. 209-249.Brixhe, Claude. "Corpus des inscriptions paléo-phrygiennes, Supplément II”, Kadmos 43, 2004, pp. 1-130. 
Brixhe, Claude, \& Lejeune, Michel. Corpus des Inscriptions Paleo-Phrygiennes I-II. "Mémoire" $\mathrm{N}^{\mathrm{0}}$ 45, Paris, 1984.

Fraser, J. "The Lydian Language". In: Buckler, William Hepburn, \& Calder, William M., (eds.), Anatolian Studies presented to Sir William Mitchell Ramsay. Publications of the University Press of Manchester, no. 160, Manchester, 1923, pp. 139-150.

Friedrich, Johannes. Kurzgefaßtes Hethitisches Wörterbuch, Heidelberg, 1991.

Gorbachov, Yaroslav. "Nine Observations on the Old Phrygian Inscription from Vezirhan", Kadmos 47, 2008, pp. 91-108.

Gusmani, Roberto. Lydisches Wörterbuch, Heidelberg, 1964.

Gusmani, Roberto. Neue epichorische Schriftzeugnisse aus Sardis 1958-1971. Archaeological exploration of Sardis, Monographs 3, Cambridge-Massachusetts, 1975.

Gusmani, Roberto. "Zum Stand der Erforschung der lydischen Sprache". In: Schwertheim, Elmar, (Hrsg.), Forschungen in Lydien. Asia Minor Studien 17, Bonn, 1995, pp. 9- 19.

Littmann, Enno. Sardis VI, Lydian Inscriptions, Leyden, 1917.

Mallory, James P., \& Adams, Douglas Q. The Oxford Introduction to Proto-Indo-European and the Proto-Indo-European World, Oxford, 2007 (reprint of 2006 edition).

Melchert, H. Craig. Cuneiform Luvian Lexicon. Lexica Anatolica Volume 2, Chapel Hill, N.C., 2001 (online version of 1993 edition).

Melchert, H. Craig. A Dictionary of the Lycian Language, Ann Arbor-New York, 2004.

Neumann, Günter. "Die zwei Inschriften auf der Stele von Vezirhan". In: Gusmani, R., Salvini, M., \& Vannicelli, P., (eds.), Frigi e frigio, Atti del $1^{\circ}$ Simposio Internazionale, Roma, 16-17 ottobre 1995, Roma, 1997, pp. 11-31.

Obrador-Cursach, Bartomeu. The Phrygian Language. Handbook of Oriental Studies, Section One: The Near East 139, Leiden-Boston, 2020.

Simon, Zsolt. "Die letzte Zeile der phrygischen Inschrift von Vezirhan", Acta Classica Universitatis Scientiarum Debreceniensis 51, 2015, pp. 17-30.

Ventris, Michael, \& Chadwick, John. Documents in Mycenaean Greek, Cambridge, 1973 (second edition).

Woudhuizen, Fred C. "Lydian: Separated from Luwian by three signs", Talanta, Proceedings of the Dutch Archaeological and Historical Society 16-17, 1984-5, pp. 91113.

Woudhuizen, Fred C. "Appendix IV: The Lydian-Aramaic Bilingual Inscription from Sardis Reconsidered", Selected Luwian Hieroglyphic Texts 2. Innsbrucker Beiträge zur Kulturwissenschaft, Sonderheft 124, Innsbruck, 2005, pp. 119-147.

Woudhuizen, Fred C. "The Transmission of the Phoenician Alphabet in the Mediterranean Region", Rivista di Studi Fenici 34/2, 2006 [2009], pp. 173-184.

Woudhuizen, Fred C. "Phrygian \& Greek", Talanta, Proceedings of the Dutch Archaeological and Historical Society 40-41, 2008-2009, pp. 181-215.

Woudhuizen, Fred C. "Two Notes on Lydian", Talanta, Proceedings of the Dutch Archaeological and Historical Society 42-43, 2010-2011, pp. 207-213.

Woudhuizen, Fred C. Selected Luwian Hieroglyphic Texts, The Extended Version. Innsbrucker Beiträge zur Sprachwissenschaft, Band 141, Innsbruck, 2011.

Woudhuizen, Fred C. "The Luwian Hieroglyphic Contribution to the Alphabet", Živa Antika 66, 2016a, pp. 5-14.

Woudhuizen, Fred C. "The Genitive Plural in Luwian Hieroglyphic and its Comparanda from the Related Luwian Languages”. In: Dündar, Erkan, Aktaş, Şevkat, Koçak, Mustafa, \& Erkoç, Serap, (eds.), Lykıarkhıssa, Festschrift für Havva İşkan, İstanbul, 2016b, pp. 881-884.

Woudhuizen, Fred C. "Selected Cuneiform Luwian Texts", Talanta, Proceedings of the Dutch Archaeological and Historical Society 48-49, 2016-2017, pp. 329-367. 
Woudhuizen, Fred C. "The Role of Brotherhoods in West-Luwian Religion $\left(5^{\text {th }}\right.$ to $2^{\text {nd }}$ century BCE)". In: Hutter, Manfred, \& Hutter-Braunsar, Silvia, (Hrg.), Economy of Religions in Anatolia: From the Early Second to the Middle of the First Millennium BCE, Proceedings of an International Conference in Bonn $\left(23^{\text {rd }}\right.$ to $25^{\text {th }}$ May 2018).

Alter Orient und Altes Testament, Veröffentlichungen zur Kultur und Geschichte des Alten Orients und des Alten Testaments, Band 467, Münster, 2019, pp. 169-180.

Yakubovich, Ilya. "An Agreement between the Sardians and the Mermnads in the Lydian language?", Indogermanische Forschungen 122/1, 2017, pp. 265-294.

Zgusta, Ladislav. Kleiasiatische Ortsnamen, Heidelberg, 1984. 
